\title{
Mutational studies on single circulating tumor cells isolated from the blood of inflammatory breast cancer patients
}

\author{
Catherine Bingham $^{1} \cdot$ Sandra V. Fernandez ${ }^{1,3} \cdot$ Patricia Fittipaldi $^{1}$ • \\ Paul W. Dempsey ${ }^{2} \cdot$ Karen J. Ruth $^{1} \cdot$ Massimo Cristofanilli $^{1,4} \cdot$ R. Katherine Alpaugh ${ }^{1,3}$
}

Received: 1 December 2016/ Accepted: 25 February 2017/Published online: 7 March 2017

(c) The Author(s) 2017. This article is published with open access at Springerlink.com

\begin{abstract}
Purpose The molecular characterization of circulating tumor cells (CTCs) is critical to identify the key drivers of cancer metastasis and devising therapeutic approaches, particularly for inflammatory breast cancer (IBC) which is usually diagnosed at advance stages and progresses rapidly. Methods Genomic alterations in tumor tissue samples were studied using Foundation One ${ }^{\mathrm{TM}}$. Single CTCs were isolated using CellSearch followed by single-cell isolation by DEPArray $^{\mathrm{TM}}$. Samples with 20 or more CTCs were chosen to isolate single CTCs using the DEPArray ${ }^{\mathrm{TM}}$.

Results Genomic alterations were studied in primary tumor or metastatic sites from 32 IBC patients. Genes with high-frequency mutations were as follows: TP53 (69\%), RB1 (16\%), PIK3CA (13\%), and also ErbB2 (3\%). At least once during treatment, CTCs were detected in 26 patients with metastatic IBC, in two patients with locally advanced IBC, and four patients had no detectable CTCs. Per $7.5 \mathrm{~mL}$ of blood, fifteen patients (47\%) had $\geq 20$ CTCs and six of them were chosen at random to isolate single CTCs. These
\end{abstract}

Electronic supplementary material The online version of this article (doi:10.1007/s10549-017-4176-x) contains supplementary material, which is available to authorized users.

Sandra V. Fernandez

Sandra.Fernandez@fccc.edu

R. Katherine Alpaugh

R.Alpaugh@fccc.edu

1 Fox Chase Cancer Center, Philadelphia, PA 19111, USA

2 Cynvenio Biosystems, Westlake Village, CA, USA

3 Protocol Support Laboratory, Fox Chase Cancer Center, 333 Cottman Ave., Philadelphia, PA 19111, USA

4 Present Address: Robert H Lurie Comprehensive Cancer Center of Northwestern University, Chicago, IL, USA cells were tested for the presence of TP53, RB1, PIK3CA, and/or ErbB2 mutations previously found in matching tissue biopsies. The isolated CTCs showed the same mutations as primary or metastatic tumor samples. Intra-patient CTC heterogeneity was found by the presence of different CTC subclones, with some CTCs harboring different combinations of mutated and wild-type genes.

Conclusions Our results indicate that CTCs could represent a non-invasive source of cancer cells from which to determine genetic markers as the disease progresses and identify potential therapeutic targets in IBC patients.

Keywords CTC $\cdot$ Single-cell analysis $\cdot$ Tumor heterogeneity $\cdot$ IBC

$\begin{array}{ll}\text { Abbreviations } \\ \text { CK } & \text { Cytokeratin } \\ \text { CTC } & \text { Circulating tumor cell } \\ \text { EpCAM } & \text { Epithelial cell adhesion molecule } \\ \text { ErbB2 or } & \text { v-erb-b2 avian erythroblastic leukemia viral } \\ \text { Her2 } & \text { oncogene homolog } 2 \\ \text { FFPE } & \text { Formalin- fixed paraffin embedded } \\ \text { Fs } & \text { Frameshift } \\ \text { IBC } & \text { Inflammatory breast cancer } \\ \text { NGS } & \text { Next-generation sequencing } \\ \text { OS } & \text { Overall survival } \\ \text { PE } & \text { Phycoerythrin } \\ \text { PgR } & \text { Progesterone receptor } \\ \text { RB1 } & \text { Retinoblastoma tumor suppressor } \\ \text { TN } & \text { Triple-negative } \\ \text { TNBC } & \text { Triple-negative breast cancer } \\ \text { WBC } & \text { White blood cells } \\ \text { WGA } & \text { Whole genome amplification }\end{array}$




\section{Introduction}

Inflammatory breast cancer (IBC) is a very aggressive type of advanced breast cancer with a poor prognosis. The clinical symptoms of IBC involve the rapid onset of changes in the skin overlaying the breast, including edema, redness, and swelling, exhibiting a wrinkled, orange peellike appearance of the skin known as peau d'orange [1]. This peculiar presentation is associated with the invasion of aggregates of tumor cells, defined as tumor emboli, into the dermal lymphatics, where they obstruct the lymph channels $[2,3]$. IBC currently accounts for only $2-6 \%$ of all breast cancer cases in the United States and up to $20 \%$ of all breast cancer cases globally [4-7]. Due to its propensity to rapidly metastasize, it is responsible for a disproportionate number (15\%) of breast cancer-related deaths [7-9]. IBC is either stage III or IV; at the time of diagnosis, virtually all patients have lymph node metastases and one third of the patients have metastases in distant organs such as the brain, the bones, and/or the visceral organs [6].

Metastatic disease is the most common cause of cancerrelated death in patients with solid tumors and it is often associated with the presence of circulating tumor cells (CTCs) in the peripheral blood of cancer patients [10]. CTCs have been detected in a majority of epithelial cancers, including prostate [11], colorectal [12], and breast cancers [13]. CTCs are tumor cells shed from either the primary tumor or its metastases and can thus be regarded as "liquid biopsies" of metastasizing cells. Although their exact composition is unknown, a fraction of these cells is thought to be viable metastatic precursors capable of initiating a clonal metastatic lesion $[14,15]$. Little is known about the timing of CTC release from primary tumors, their functional properties, or their heterogeneity. Intra-tumor heterogeneity denotes the coexistence of subpopulations of cancer cells that differ in their genetic, phenotypic, or behavioral characteristics within a given primary tumor and between a given primary tumor and its metastasis. Thus, intra-tumor heterogeneity poses a tremendous challenge for the characterization of biomarkers and treatments selection. In this work, we isolated single CTCs from the blood of IBC patients in order to analyze the presence of different mutations found in the primary tumor or metastatic sites and determine the heterogeneity of these cells.

\section{Materials and methods}

\section{Patients}

Thirty-two patients with inflammatory breast cancer (IBC) undergoing systemic treatment for their disease were included in this study. At the time of the first CTC enumeration, 29 patients had metastatic IBC (Stage IV) and three patients had locally advance IBC (Stage III). Clinical details and treatment timelines for the 32 patients are given in Supplementary Information. Targeted treatment outcomes have also been reported elsewhere on patients D84455 [16] and I77438 [17].

\section{Genomic studies in tumor samples}

Formalin-fixed paraffin embedded (FFPE) tumor tissues (breast, chest wall, lymph node, bone marrow, liver biopsy, abdominal skin punch, brain biopsy, and/or pleural fluids) were used for genomic studies. Ten unstained sections were cut $(5-10 \mu \mathrm{m})$ and placed on charged slides and submitted to Foundation Medicine (Cambridge, MA) for genetic analysis. Briefly, DNA was isolated from the fixed tumor cells and genomic analysis was performed using next-generation sequencing (NGS) (Foundation One ${ }^{\mathrm{TM}}$ ).

\section{CTCs enumeration from the blood using CellSearch}

One tube of $7.5 \mathrm{~mL}$ blood from the IBC patients was drawn and the CellSearch ${ }^{\mathrm{TM}}$ System was used for CTC enrichment and enumeration. After running the blood in the CellSearch $^{\mathrm{TM}}$ system for CTC enumeration, the cells were recovered from the cassettes in order to be used for single CTC selection using the DEPArray ${ }^{\mathrm{TM}}$ System (Silicon Biosystems, San Diego, CA). The standard protocol used for CTC enrichment is described in Supplemental Materials and Methods. Samples containing a minimum of 20 CTCs were selected and prepared for single-cell selection using the DEPArray ${ }^{\mathrm{TM}}$.

\section{Isolation of single CTCs using the DEPArray ${ }^{\mathrm{TM}}$ system}

After the CellSearch enrichment, single CTCs were selected and isolated using the DEPArray ${ }^{\mathrm{TM}}$ (Silicon Biosystems) as described in Supplemental Materials and Methods. Individual CTCs or clustered cells that were $\alpha$ cytokeratin (PE)-positive, CD45 (APC)-negative, and DAPI-positive were recovered in several tubes for genomic analysis. In addition, individual white blood cells (WBC) classified as CD45 (APC)-positive, CK (PE)-negative, and DAPI-positive were selected and recovered as single cells to use as controls in the genomic studies. Selected cells were stored at $-80{ }^{\circ} \mathrm{C}$ for genomic analyses.

\section{TP53, ErbB2, PIK3CA, and RB1 mutations in CTCs}

Whole genome amplification (WGA) was performed using the Ampli1 ${ }^{\mathrm{TM}}$ WGA Kit (Silicon Biosystems). The 
Table 1 Mutations in tumor samples and number of CTCs detected during disease progression in triple-negative IBC patients

\begin{tabular}{|c|c|c|c|c|c|c|c|c|c|c|c|}
\hline \multirow[t]{2}{*}{ Patient ID } & \multirow[t]{2}{*}{$\begin{array}{c}\text { Age at } \\
\text { diagnosis }\end{array}$} & \multicolumn{3}{|c|}{ Tissue } & \multicolumn{6}{|c|}{$\begin{array}{l}\text { Number of CTCs ( in } 7.5 \mathrm{ml} \text { blood) and } \\
\text { IBC stage at that point }\end{array}$} & \multirow[t]{2}{*}{$\begin{array}{c}\text { Survival } \\
\text { time }\end{array}$} \\
\hline & & Tissue source & Mutation & Amplification & Baseline & $\begin{array}{c}\text { Month } \\
1-10\end{array}$ & $\begin{array}{l}\text { Month } \\
11-20\end{array}$ & $\begin{array}{l}\text { Month } \\
21-30\end{array}$ & $\begin{array}{c}\text { Month } \\
31-40\end{array}$ & $\begin{array}{l}\text { Month } \\
41-50\end{array}$ & \\
\hline $\begin{array}{l}\mathrm{J} 73299 \\
\end{array}$ & 34 & $\begin{array}{c}\text { Liver } \\
\text { (month 13) }\end{array}$ & $\begin{array}{l}\text { TP53 P190 H193 >*E } \\
\text { BRCA1 E23 fs* } * 17\end{array}$ & $\begin{array}{l}\text { AKT1, RPTOR } \\
\text { MCL1, } \\
\text { MYC }\end{array}$ & $\begin{array}{l}\text { NDA } \\
\text { (III) }\end{array}$ & $\begin{array}{c}\mathrm{ND} \\
\text { (III) } \\
\dagger \\
\end{array}$ & $\begin{array}{c}101 \\
(I V) \\
+\end{array}$ & $\begin{array}{c}201 \\
(I V) \\
+\end{array}$ & & & 21 months \\
\hline $\begin{array}{c}777549 \\
\end{array}$ & 47 & $\begin{array}{l}\text { Chest wall } \\
\text { (month 22) }\end{array}$ & RB1 splice $607+1 \mathrm{G}>\mathrm{C}$ & & $\begin{array}{l}\text { NDA } \\
\text { (III) }\end{array}$ & NDA & $\begin{array}{c}60 \\
(\mathrm{IV}) \\
\dagger\end{array}$ & $\begin{array}{c}2,502 \\
(\mathrm{IV}) \\
\dagger\end{array}$ & & & 27 months \\
\hline D84455 & 57 & $\begin{array}{l}\text { Chest wall } \\
\text { (month 21) }\end{array}$ & $\begin{array}{l}\text { TP53 C229 fs*10 } \\
\text { ERBB2 V777L } \\
\text { ERBB2 S310F } \\
\text { PIK3CA K111E }\end{array}$ & & $\begin{array}{l}\text { NDA } \\
\text { (IV) }\end{array}$ & NDA & $\begin{array}{c}25^{+} \\
(\mathrm{IV}) \\
\dagger\end{array}$ & $\begin{array}{c}46^{+} \\
(\mathrm{IV}) \\
\dagger\end{array}$ & $\begin{array}{c}19^{+} \\
(\mathrm{IV}) \\
+\end{array}$ & & 31 months \\
\hline R85453 & 45 & $\begin{array}{c}\text { Breast } \\
\text { (month 8) }\end{array}$ & TP53 R110 fs*13 & $\begin{array}{l}\text { MCL1, } \\
\text { MYC, } \\
\text { JUN }\end{array}$ & $\begin{array}{l}\text { NDA } \\
\text { (III) }\end{array}$ & $\begin{array}{c}33 \\
(I V) \\
\dagger\end{array}$ & $\begin{array}{c}222 \\
(I V) \\
\dagger\end{array}$ & & & & 15 months \\
\hline $\begin{array}{ll}\text { L67504 } \\
\end{array}$ & 43 & $\begin{array}{l}\text { Chest wall } \\
(\text { month 44) }\end{array}$ & $\begin{array}{l}\text { TP53 R110 fs*13 } \\
\text { BRAC2 A1326 fs*4 } \\
\text { RB1 K720* }\end{array}$ & $\begin{array}{l}\text { CCNE1, } \\
\text { MYC }\end{array}$ & $\begin{array}{l}\text { NDA } \\
\text { (III) }\end{array}$ & NDA & $\mathrm{NDA}$ & $\begin{array}{c}20 \\
(I V) \\
\dagger\end{array}$ & $\begin{array}{c}12^{+} \\
(\mathrm{IV}) \\
\dagger\end{array}$ & $\begin{array}{c}90^{+} \\
(\mathrm{IV}) \\
\dagger\end{array}$ & 51 months \\
\hline T81354 & 45 & $\begin{array}{l}\text { Lymph node } \\
\text { (month 19) }\end{array}$ & \begin{tabular}{|l|} 
TP53 splice site \\
782+1CT \\
RB1 P777 fs*33
\end{tabular} & & $\begin{array}{l}\text { NDA } \\
\text { (IV) }\end{array}$ & $\begin{array}{c}9 \\
(\mathrm{IV}) \\
+\end{array}$ & $\begin{array}{c}4 \\
(\mathrm{IV}) \\
+\end{array}$ & NDA & NDA & NDA & 45 months \\
\hline S80274 & 61 & $\begin{array}{l}\text { Chest wall } \\
(\text { month 20) }\end{array}$ & TP53 G245S, G245D & & $\begin{array}{l}\text { NDA } \\
\text { (III) }\end{array}$ & NDA & $\begin{array}{c}3 \\
(I V) \\
+\end{array}$ & $\begin{array}{c}9 \\
(I V) \\
\dagger\end{array}$ & $\begin{array}{c}\text { ND } \\
+\end{array}$ & & 31 months \\
\hline $\begin{array}{l}\mathrm{J} 64403 \\
\end{array}$ & 52 & $\begin{array}{l}\text { Skin central upper } \\
\text { abdomen } \\
\text { (month 43) }\end{array}$ & $\begin{array}{l}\text { BRAC2 L1768 fs*5 } \\
\end{array}$ & & $\begin{array}{l}\text { NDA } \\
\text { (III) }\end{array}$ & NDA & $\mathrm{NDA}$ & $\begin{array}{c}1 \\
(I V) \\
\dagger\end{array}$ & $\begin{array}{c}0 \\
(\mathrm{IV}) \\
\dagger\end{array}$ & $\begin{array}{c}9 \\
(\mathrm{IV}) \\
+\end{array}$ & 48 months \\
\hline $\begin{array}{l}\mathrm{D} 89802 \\
\end{array}$ & 44 & $\begin{array}{l}\text { Chest wall } \\
\text { (month 1) }\end{array}$ & $\begin{array}{l}\text { TP53 R248Q } \\
\text { MEN1 E496* }\end{array}$ & CCND1 & $\begin{array}{l}\text { NDA } \\
\text { (IV) }\end{array}$ & $\begin{array}{c}2 \\
(\mathrm{IV}) \\
+\end{array}$ & $\begin{array}{l}\mathrm{ND} \\
+ \\
\end{array}$ & & & & 19 months \\
\hline $\begin{array}{c}\mathrm{C} 65525 \\
\mathrm{n}\end{array}$ & 55 & $\begin{array}{l}\text { Chest wall } \\
\text { (month 30) }\end{array}$ & TP53 S241 fs*23 & AKT2 & $\begin{array}{l}\text { NDA } \\
\text { (III) }\end{array}$ & NDA & $\begin{array}{c}0 \\
(I V) \\
+\end{array}$ & $\begin{array}{c}12 \\
(I V) \\
+\end{array}$ & $\begin{array}{c}4 \\
(I V) \\
+ \\
\end{array}$ & & 38 months \\
\hline $\begin{array}{c}\begin{array}{c}\text { B87480 } \\
\text { (male) }\end{array} \\
\text { mate }\end{array}$ & 65 & $\begin{array}{l}\text { Chest wall } \\
\text { (month 13) }\end{array}$ & $\begin{array}{l}\text { Kras G12D } \\
\text { NOTCH1 E424K }\end{array}$ & & $\begin{array}{l}\text { NDA } \\
\text { (IV) }\end{array}$ & NDA & $\begin{array}{c}0 \\
(\mathrm{IV}) \\
\dagger\end{array}$ & NDA & NDA & & 36 months \\
\hline R67904 & 72 & $\begin{array}{l}\text { Lymph node } \\
\text { (month 1) }\end{array}$ & $\begin{array}{l}\text { TP53 W146*, } \\
\text { ATM E672 fs*31 }\end{array}$ & $\begin{array}{l}\text { CCND1, MCL1 } \\
\text { MYC, } \\
\text { NKX2-1 }\end{array}$ & $\begin{array}{c}6 \\
(I V) \\
+ \\
+\end{array}$ & $\begin{array}{c}0 \\
(I V) \\
\dagger\end{array}$ & $\begin{array}{c}34 \\
(I V) \\
+\end{array}$ & $\begin{array}{c}\text { ND } \\
(I V) \\
\dagger\end{array}$ & & & 22 months \\
\hline M76085 & 51 & $\begin{array}{l}\text { Chest wall } \\
\text { (month 27) }\end{array}$ & NOTCH1 loss & & $\begin{array}{l}\text { NDA } \\
\text { (IV) }\end{array}$ & NDA & $\mathrm{NDA}$ & $\begin{array}{c}3 \\
(\mathrm{IV}) \\
+\end{array}$ & $\begin{array}{c}\text { ND } \\
+ \\
\end{array}$ & & 32 months \\
\hline $\begin{array}{l}\text { M67752 } \\
\end{array}$ & 61 & $\begin{array}{l}\text { Skin of right upper back } \\
\text { medial } \\
\text { (month 27) }\end{array}$ & TP53 R342* & $\begin{array}{l}\text { FGFR1 } \\
\end{array}$ & $\begin{array}{l}\text { NDA } \\
\text { (IV) }\end{array}$ & $\begin{array}{c}0 \\
(\mathrm{IV}) \\
\dagger\end{array}$ & $\begin{array}{c}0 \\
(\mathrm{IV}) \\
+\end{array}$ & $\begin{array}{c}28 \\
(\mathrm{IV}) \\
+\end{array}$ & $\begin{array}{c}\mathrm{ND} \\
+ \\
\end{array}$ & & 32 months \\
\hline E91111 & 40 & $\begin{array}{l}\text { Bone marrow } \\
\text { (month 34) }\end{array}$ & \begin{tabular}{|l|} 
TP53 G245C, \\
BRCA1 R1583 fs*39, \\
EPHA3 E237K
\end{tabular} & $\begin{array}{l}\text { AKT3, } \\
\text { JAK2 }\end{array}$ & $\begin{array}{l}\text { NDA } \\
\text { (III) }\end{array}$ & NDA & NDA & $\begin{array}{c}0 \\
(\mathrm{IV}) \\
\dagger\end{array}$ & $\begin{array}{c}8 \\
(I V) \\
\dagger \\
\end{array}$ & & 39 months \\
\hline L95781 & 44 & $\begin{array}{l}\text { Chest wall } \\
\text { (month 8) }\end{array}$ & $\begin{array}{l}\text { TP53 L257fs*8, splice } \\
\text { site 920-2 A>G } \\
\text { NOTCH1 H2428 fs*6 }\end{array}$ & MCL1 & $\begin{array}{l}\text { NDA } \\
\text { (IV) }\end{array}$ & $\begin{array}{c}117 \\
(I V) \\
\dagger\end{array}$ & & & & & 9 months \\
\hline L92225 & 53 & $\begin{array}{l}\text { Pleural fluid (month } \\
\text { a) } \\
\text { and } \\
\text { Abdominal skin punch } \\
\text { (month 16) } \\
\end{array}$ & \begin{tabular}{|l|} 
AKT1 E17K \\
TP53 D259Y \\
RB1 E693* \\
CDH1 S337_L343 del
\end{tabular} & & $\begin{array}{l}\text { NDA } \\
\text { (IV) }\end{array}$ & NDA & $\begin{array}{c}178 \\
\text { (IV) } \\
\dagger\end{array}$ & & & & 20 months \\
\hline T89857 & 42 & $\begin{array}{c}\text { Right breast } \\
\text { (month 7) }\end{array}$ & \begin{tabular}{|l|} 
TP53 R156fs*14 \\
PIK3CA E8_L15>G
\end{tabular} & $\begin{array}{l}\text { MCL1 } \\
\text { MYC }\end{array}$ & $\begin{array}{l}\text { NDA } \\
\text { (III) }\end{array}$ & $\begin{array}{c}3 \\
(\mathrm{III}) \\
\dagger \\
\end{array}$ & $\begin{array}{c}0 \\
(I V) \\
+\end{array}$ & & & & 19 months \\
\hline
\end{tabular}


Table 1 continued

\begin{tabular}{|c|c|c|c|c|c|c|c|c|c|c|c|}
\hline Patient ID & $\begin{array}{c}\text { Age at } \\
\text { diagnosis }\end{array}$ & \multicolumn{3}{|c|}{ Tissue } & \multicolumn{6}{|c|}{$\begin{array}{c}\text { Number of CTCs ( in } 7.5 \mathrm{ml} \mathrm{blood)} \mathrm{and} \\
\text { IBC stage at that point }\end{array}$} & $\begin{array}{c}\text { Survival } \\
\text { time }\end{array}$ \\
\hline \multirow[t]{2}{*}{ D66122 } & 44 & $\begin{array}{c}\text { Breast } \\
\text { (month 8) }\end{array}$ & $\begin{array}{l}\text { TP53 P98 ff*18 } \\
\text { SOX10 A361V }\end{array}$ & RAF1 & $\begin{array}{l}\text { NDA } \\
\text { (III) }\end{array}$ & $\begin{array}{c}\text { ND } \\
\dagger\end{array}$ & $\begin{array}{c}21^{+} \\
\text {(IV) } \\
+\end{array}$ & $\begin{array}{c}140^{+} \\
\text {(IV) } \\
+\end{array}$ & $\begin{array}{c}39^{+} \\
\text {(IV) } \\
+\end{array}$ & & 34 months \\
\hline & & $\begin{array}{l}\text { Skin chest wall } \\
\text { (month 26) }\end{array}$ & TP53 Q104 fs*19 & ERBB2 & & & & & & & \\
\hline K93878 & 42 & $\begin{array}{l}\text { Left breast } \\
\text { (month 43) }\end{array}$ & $\begin{array}{l}\text { TP53 S99 fs*44 } \\
\text { RB1 L779* }\end{array}$ & $\begin{array}{l}\text { MYC, } \\
\text { MDM4 }\end{array}$ & $\begin{array}{c}\text { NDA } \\
\text { (III) }\end{array}$ & NDA & NDA & NDA & NDA & $\begin{array}{c}127 \\
\text { (IV) } \\
\dagger\end{array}$ & 44 months \\
\hline
\end{tabular}

Mutations and gene amplifications in tumor samples are shown. Time of tissue collection $(t=0$; time of diagnosis) is indicated in each case. The survival time since IBC diagnostic is indicated. Several blood samples were run in order to determine the number of CTCs along the patient's treatment; in the table, only the highest numbers of CTCs during each 10 month period are indicated (in Supplementary Information, all the points are shown). Also, the disease stage at the time of CTC enumeration is indicated

In some patients, CTCs were present as clusters; presence of CTCs clusters are indicated as $(+)$. Baseline: CTCs number before neoadjuvant treatment; NDA no data available because the patient was treated at another institution; ND not-done

The time when patients came to Fox Chase Cancer Center for treatment recommendations and/or blood samples draw for CTC enumeration are indicated as $(\dagger)$

Ampli1 ${ }^{\text {TM }}$ WGA kit uses a polymerase with proofreading activity with a lower error rate $\left(4.8 \times 10^{-6}\right)$ than standard Taq DNA polymerases. Global amplification consisting of DNA isolation, restriction digestion, adaptor ligation, and PCR amplification was performed as described in Supplemental Materials and methods [18]. To study TP53, ErbB2, and PIK3CA mutations in CTCs, reverse and forward primers were used (Supplementary Table 1). The PCR products were cleaned using the QIAquick PCR purification kit and sequenced using the ABI 3130XL capillary genetic analyzer. As we were unsuccessful in studying RB1 K720* mutation using specific primers as described before for other genes, this mutation was studied using nextgeneration sequencing (NGS) as described in Supplemental Materials and Methods.

\section{Results}

\section{Mutation analysis of tissue samples from metastatic IBC patients}

A total of 32 patients with IBC were included in the study (Tables 1 and 2). All the patients were females save one male (B87480, Table 1), and all of them were at an advanced clinical stage at time of diagnosis (stage III or IV). Their median age at diagnosis was 48 years with a range of 32-72 years old. From the 32 patients, 20 patients $(62.5 \%)$ had triple-negative (ER-negative, PgR-negative, and Her2-negative) IBC (Table 1); five patients (15.6\%) had ER-positive Her2-negative IBC; three patients (9.4\%) had ER-negative Her2-positive IBC; and four patients
(12.5\%) had ER-positive Her2-positive IBC at time of diagnosis (Table 2).

The genomic alterations in the primary tumor or metastatic sites were determined using the NGS-based cancer gene test, Foundation One ${ }^{\mathrm{TM}}$ (Tables 1 and 2). IBC patients showed mutations in the following: TP53 (22/32; $69 \%)$, RB1 (5/32; 16\%), PIK3CA (4/32; 13\%), BRCA1 (3/ $32 ; 9 \%)$, BRCA2 $(3 / 32 ; 9 \%)$, and Notch $1(3 / 32 ; 9 \%)$. Other mutated genes were ErbB2 (or Her2; 3\%), ATM, Kras, ESR1, EGFR, and PAX5. Also IBC tumor samples showed amplifications in the following: MYC $(8 / 32 ; 25 \%)$, CCND1 (7/32; 22\%), ErbB2 (5/32; 16\%), MCL1 (6/32; $19 \%$ ), and FGFR1 (3/32; 9\%). Interestingly, patient D66122, who was found to have a triple-negative disease by the analysis of her first biopsy, a second chest wall biopsy in month 26 showed amplification of the ErbB2 gene. Based on these results, this patient was subsequently treated with Herceptin (Table 1 and Supplementary Information).

\section{Circulating tumor cells (CTCs) enumeration}

The number of CTCs present in $7.5 \mathrm{~mL}$ of blood was determined at different points during the patients' treatments using the CellSearch ${ }^{\mathrm{TM}}$ system. From the 32 IBC patients, CTCs were detected in 28 patients $(\geq 5 \mathrm{CTCs} /$ $7.5 \mathrm{~mL}$ blood in 24 patients; $<5 \mathrm{CTCs} / 7.5 \mathrm{~mL}$ blood in four patients) at least once during treatment, while four patients had no detectable CTCs at any point during treatment (Tables 1 and 2). CTCs were detected in 26 patients with metastatic IBC and two patients with locally advance IBC. From 20 patients with triple-negative IBC, 
Table 2 Mutations in tumor samples and number of CTCs detected during disease progression in ER-positive Her2-negative, ER-negative Her2positive, and ER-positive Her2-positive IBC patients

\begin{tabular}{|c|c|c|c|c|c|c|c|c|c|c|c|c|c|c|c|c|c|}
\hline \multicolumn{18}{|c|}{ ER-positive Her-2 negative } \\
\hline $\begin{array}{c}\text { Patient } \\
\text { ID }\end{array}$ & Age & ER & PgR & Her2 & \multicolumn{3}{|c|}{ Tissue } & \multicolumn{9}{|c|}{$\begin{array}{c}\text { Number of CTCs / } 7.5 \mathrm{ml} \text { blood } \\
\text { (IBC stage at that point) }\end{array}$} & $\begin{array}{c}\text { Survival } \\
\text { time }\end{array}$ \\
\hline & & & & & Tissue source & Mutation & Amplific. & Baseline & $\begin{array}{c}\text { Month } \\
1-10\end{array}$ & $\begin{array}{c}\text { Month } \\
11-20\end{array}$ & $\begin{array}{l}\text { Month } \\
21-30\end{array}$ & \begin{tabular}{|c|} 
Month \\
$31-40$ \\
\end{tabular} & \begin{tabular}{|l|} 
Month \\
$41-50$ \\
\end{tabular} & \begin{tabular}{|c|} 
Month \\
$51-60$
\end{tabular} & \begin{tabular}{|c|} 
Month \\
$61-70$ \\
\end{tabular} & $\begin{array}{l}\text { Month } \\
71-80\end{array}$ & \\
\hline M71182 & 34 & pos & pos & neg & $\begin{array}{l}\text { Chest wall } \\
\text { (month 69) }\end{array}$ & $\begin{array}{l}\text { PIK3CA H1047R } \\
\text { ESR1 D538G }\end{array}$ & CCND1 & $\begin{array}{l}\text { NDA } \\
\text { (III) }\end{array}$ & NDA & $\mathrm{NDA}$ & $\mathrm{NDA}$ & NDA & NDA & $\begin{array}{c}3 \\
\text { (IV) } \\
+\dagger\end{array}$ & $\begin{array}{c}11 \\
(\mathrm{IV}) \\
\dagger\end{array}$ & $\begin{array}{l}48 \\
\text { (IV) } \\
\dagger\end{array}$ & 76 months \\
\hline D84055 & 58 & pos & pos & neg & $\begin{array}{l}\text { Left breast } \\
\text { (month 1) }\end{array}$ & & $\begin{array}{c}\text { CCND1, } \\
\text { CDK4, MDM2 }\end{array}$ & $\begin{array}{l}\text { NDA } \\
\text { (IV) }\end{array}$ & NDA & NDA & NDA & NDA & \begin{tabular}{|l|} 
NDA \\
\end{tabular} & $\begin{array}{c}2 \\
\text { (IV) } \\
\vdots \\
\dagger\end{array}$ & $\begin{array}{c}0 \\
\begin{array}{c}\text { IV) } \\
\dagger\end{array} \\
\vdots\end{array}$ & NDA & 82 months \\
\hline $\begin{array}{ll}\text { M85099 } \\
\end{array}$ & 44 & pos & pos & neg & $\begin{array}{c}\text { Pleural fluid } \\
\text { (month 29) }\end{array}$ & TP53 R273H, R181C & $\begin{array}{l}\text { FGFR2, IKBKE, } \\
\text { CCND1, MCL1 }\end{array}$ & $\begin{array}{l}\text { NDA } \\
\text { (III) }\end{array}$ & NDA & $\begin{array}{c}1 \\
\text { (IV) } \\
\dagger\end{array}$ & $\begin{array}{c}6 \\
\text { (IV) } \\
\dagger\end{array}$ & $\begin{array}{c}11 \\
\text { (IV) } \\
\dot{\dagger}\end{array}$ & $\begin{array}{c}\mathrm{ND} \\
\dagger\end{array}$ & & & & 50 months \\
\hline A89555 & 44 & pos & neg & neg & $\begin{array}{c}\text { Right breast } \\
\text { (month 2) }\end{array}$ & \begin{tabular}{|l} 
TP53 splice site $993+1 \mathrm{C}>\mathrm{T}$ \\
\end{tabular} & $\begin{array}{l}\text { CCND1, } \\
\text { MYC }\end{array}$ & $\begin{array}{c}\text { NDA } \\
\text { (III) }\end{array}$ & NDA & NDA & NDA & ND & $\begin{array}{c}1 \\
\text { (IV) } \\
\vdots\end{array}$ & $\begin{array}{c}0 \\
\text { (IV) } \\
\dagger\end{array}$ & NDA & NDA & 101 months \\
\hline $\begin{array}{ll}\text { M66830 } \\
\end{array}$ & 45 & pos & neg & neg & $\begin{array}{l}\begin{array}{l}\text { Left breast } \\
\text { (month 6) }\end{array} \\
\text { (m) }\end{array}$ & & FGFR1 & $\begin{array}{c}345 \\
\text { (III) } \\
\bar{\dagger}\end{array}$ & $\begin{array}{c}\mathrm{ND} \\
\dagger\end{array}$ & $\begin{array}{l}4 \\
\text { (IV) } \\
\dagger\end{array}$ & $\begin{array}{c}189 \\
\text { (IV) } \\
\dagger\end{array}$ & NDA & & & & & 39 months \\
\hline \multicolumn{18}{|c|}{ ER-negative Her-2 positive } \\
\hline N88166 & 60 & neg & neg & pos & $\begin{array}{l}\text { Chest wall } \\
\text { (month 19) }\end{array}$ & \begin{tabular}{|l|} 
TP53 H179R, \\
PIK3R1 441N_452Ydel
\end{tabular} & ERBB2 & $\begin{array}{c}\text { NDA } \\
\text { (III) }\end{array}$ & NDA & $\begin{array}{c}1 \\
\text { (IV) } \\
\vdots \\
\end{array}$ & $\begin{array}{c}7 \\
\text { (IV) } \\
\dagger \\
\end{array}$ & & & & & & 23 months \\
\hline S71769 & 37 & neg & neg & pos & $\begin{array}{c}\text { Brain } \\
\text { (month 18) }\end{array}$ & & ERBB2 & $\begin{array}{c}\text { NDA } \\
\text { (III) }\end{array}$ & $\begin{array}{c}\mathrm{ND} \\
+\end{array}$ & $\begin{array}{c}0 \\
\text { (IV) } \\
\dagger\end{array}$ & $\begin{array}{c}\mathrm{ND} \\
\dagger\end{array}$ & NDA & \begin{tabular}{|l|} 
NDA \\
\end{tabular} & NDA & & & 59 months \\
\hline 177438 & 51 & neg & pos & pos & $\begin{array}{l}\text { Chest wall } \\
\text { (month 22) }\end{array}$ & \begin{tabular}{|l|l} 
TP53 K132N \\
PIK3CA H1047R \\
EGFR L858R \\
\end{tabular} & ERBB2 & $\begin{array}{l}\text { NDA } \\
\text { (IV) }\end{array}$ & NDA & $\begin{array}{c}0 \\
\text { (IV) } \\
\vdots \\
\end{array}$ & $\begin{array}{c}\mathrm{ND} \\
+\end{array}$ & NDA & & & & & 39 months \\
\hline \multicolumn{18}{|c|}{ ER-positive Her2-positive } \\
\hline L88046 & 32 & pos & neg & pos & $\begin{array}{c}\text { Breast } \\
\text { (month 13) }\end{array}$ & \begin{tabular}{|l} 
TP53 A159V \\
PAX5 I301T
\end{tabular} & ERBB2 & $\begin{array}{l}\text { NDA } \\
\text { (IV) }\end{array}$ & $\overline{\mathrm{NDA}}$ & $\mathrm{NDA}$ & NDA & $\begin{array}{c}5 \\
\text { IV) } \\
\vdots\end{array}$ & $\mathrm{ND}$ & & & & 43 months \\
\hline $\mathrm{J} 70105$ & 50 & pos & neg & pos & $\begin{array}{l}\text { Chest wall } \\
\text { (month 28) }\end{array}$ & & $\begin{array}{l}\text { AKT1, AURKA, } \\
\text { FGFR1, } \\
\text { MYC }\end{array}$ & $\begin{array}{l}\mathrm{ND} \\
\text { (III) }\end{array}$ & NDA & NDA & $\begin{array}{c}0 \\
\text { (III) } \\
\dagger\end{array}$ & $\begin{array}{c}\text { ND } \\
\text { (III) } \\
\dagger \\
\end{array}$ & NDA & NDA & NDA & NDA & 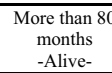 \\
\hline K76386 & 56 & pos & neg & pos & $\begin{array}{l}\text { Chest wall } \\
\text { (month 15) }\end{array}$ & \begin{tabular}{|l|} 
PTEN D107Y \\
BRAC1 truncation \\
BRAC2 truncation
\end{tabular} & & $\begin{array}{l}\text { NDA } \\
\text { (III) }\end{array}$ & $\begin{array}{c}111 \\
\text { (IV) } \\
\dagger\end{array}$ & $\begin{array}{c}32 \\
\text { (IV) } \\
\dagger\end{array}$ & $\begin{array}{c}\mathrm{ND} \\
+\end{array}$ & & & & & & 21 months \\
\hline \multirow[t]{2}{*}{$\mathrm{B} 62630$} & \multirow[t]{2}{*}{37} & \multirow[t]{2}{*}{ pos } & \multirow[t]{2}{*}{ pos } & \multirow[t]{2}{*}{ pos } & $\begin{array}{l}\text { Chest wall } \\
\text { (month 49) }\end{array}$ & \begin{tabular}{|l|} 
TP53 S215G \\
\end{tabular} & CCNE1 & \multirow[t]{2}{*}{$\begin{array}{l}\text { ND } \\
\text { (III) }\end{array}$} & \multirow[t]{2}{*}{ NDA } & \multirow[t]{2}{*}{ NDA } & \multirow[t]{2}{*}{ NDA } & \multirow[t]{2}{*}{ NDA } & \multirow{2}{*}{$\begin{array}{c}29^{+} \\
\text {(IV) } \\
\dagger\end{array}$} & \multirow{2}{*}{\begin{tabular}{|c}
$43^{+}$ \\
(IV) \\
$\dagger$
\end{tabular}} & & & \multirow[t]{2}{*}{56 months } \\
\hline & & & & & $\begin{array}{c}\text { Pleural fluid } \\
\text { (month 50) }\end{array}$ & & $\begin{array}{c}\text { CCND1, IGF1R, } \\
\text { MDM2, } \\
\text { AURKA,SRC }\end{array}$ & & & & & & & & & & \\
\hline
\end{tabular}

Mutations and amplifications in tumor samples are shown. The age of the patients, the ER/PgR/Her2 status at diagnosis, and survival time since IBC diagnosis are indicated

The number of CTCs present in $7.5 \mathrm{~mL}$ of blood was determined using the CellSearch system

Blood samples were run in order to determine the number of CTCs during the disease progression; only the highest numbers of CTCs, every 10 -month period since time of start of treatment, are showed

$N D A$ no data available because the patient was treated in another institution, $N D$ non-done, + presence of clusters

Baseline number of CTCs before treatment

16 patients had $\geq 5 \mathrm{CTCs} / 7.5 \mathrm{~mL}$ blood, and four patients had 0-4 CTCs $/ 7.5 \mathrm{~mL}$ blood. Patients with triple-negative IBC had significantly worse overall survival compared to those with ER-positive Her2-positive IBC $(p=0.011)$, ER-positive Her2-negative IBC $(p=0.001)$, and ER-negative Her2-positive IBC $(p=0.027)$ (Fig. 1). Patients in the ER-positive Her2-negative group had the longest median survival (ER-positive Her2-negative $=76$ months $(95 \%$ CI 39-101), Triple-Negative $=31.5$ months $(95 \%$ CI 20-38), ER-negative Her2-positive $=39$ months $(95 \%$ CI 23-59.), ER-positive Her2-positive $=49.5$ months (95\% CI 21-undet.) (Figure 1). In the ER-positive Her2positive group at the time of diagnosis (Table 2), patient
K76386 developed a ER-positive (weak) Her2-negative component in month 9; and a tumor biopsy performed from patient B62630 in month 49 showed that the tumor was ER-positive Her2-negative (Supplementary Information). CTCs were detected in 26 patients with metastatic IBC (Stage IV) and in two patients with locally advance IBC (Stage III) at least once during treatments (Tables 1 and 2). CTCs were not detected in patient B87480 with triplenegative IBC (Table 1) nor in patients S71769, I77438, and J70105 with Her2-positive IBC (Table 2).

In order to successfully isolate single CTC using the DEPArray, samples from the CellSearch that contain at least 20 CTCs were used. Per $7.5 \mathrm{~mL}$ of blood from the 32 
IBC patients, fifteen $(47 \%)$ patients had $\geq 20$ CTCs, two (6\%) patients had 10-20 CTCs, five patients (16\%) had between 5 and $10 \mathrm{CTC}$, and six patients (19\%) had 1-5 CTCs. Of the 20 patients with triple-negative IBC, CTCs were detected in 19 of them at some point during the course of their disease, and 11 of these patients $(55 \%)$ had more than 20 CTCs per $7.5 \mathrm{~mL}$ of blood (Table 1). CTCs were detected in all five patients with ER-positive Her2-negative IBC at least once during their treatment and two of these patients had more than 20 CTCs per $7.5 \mathrm{~mL}$ of blood (Table 2). Of the seven patients with Her2- positive IBC, three patients did not show any CTCs (although CTCs were enumerated only once in them), and two patients had more than 20 CTCs (Table 2). The two ER-positive Her2-positive IBC patients with a high number of CTCs were initially responsive to Herceptin therapy but during disease progression they failed to respond to the treatment (K76386 and B62630; Table 2).

\section{Mutations in single circulating tumor cell (CTC)}

From the fifteen patients that had $\geq 20 \mathrm{CTCs}$, six were chosen at random in order to isolate single CTCs using the DEPArray $^{\mathrm{TM}}$ (Table 3). Among these patients, all but patient B62630 had triple-negative IBC at diagnosis but, developed a Her2-negative component during disease progression as it was previously mentioned (Supplementary Information). For molecular characterization of single
CTCs, cells were recovered from the CellSearch cassettes after enumeration as it was described in Supplementary Materials and Methods, washed and loaded in the DEPArray cassettes for single-cell isolation. The DEPArray $^{\mathrm{TM}}$ system (Silicon Biosystems, San Diego, CA) is an automated platform that uses dielectrophoresis and a highquality image-based cell selection system that allows for the identification and recovery of individual cells from heterogeneous samples [18]. CTCs that were discrete single cells were seen in the blood of three patients (J73299, R85453 and T77549), whereas the remaining three patients (B62630, L67504, and D84455) had both individual single CTCs and clusters of associated CTCs (Table 3). Usually, CTCs clusters were composed by five to 14 associated cells (Fig. 2). Samples containing single CTCs, pooled single CTCs, and/or CTCs clusters were selected and recovered using DEPArray ${ }^{\mathrm{TM}}$, and the samples were tested for the presence of mutations previously revealed in tumor samples from the same patient. WGA was performed on the isolated CTCs and regions of TP53, ErbB2, and PIK3CA shown to be mutated in matching tumor tissue were amplified and sequenced using Sanger's method. In five of the six IBC patients where TP53 was mutated in the tumor tissues, the isolated CTCs showed the same TP53 mutations (Table 3). However, a TP53 S215G mutation was present in a chest wall biopsy in patient B62630, which was not observed in either the isolated CTCs or in tumor cells collected from pleural effusion (Table 2, pleural effusion
Fig. 1 Survival curves according to ER (estrogen receptor) and Her2 (ErbB2) status. Overall survival in the triple-negative group was lower than the other groups (TN vs $\mathrm{ER}-\mathrm{Her} 2+, p=0.011 ; \mathrm{TN}$ vs $\mathrm{ER}+\mathrm{Her} 2+, p=0.001 ; \mathrm{TN}$ vs $\mathrm{ER}+\mathrm{Her} 2-, p=0.027$ ). Patients from the ER+ Her2group had the longest median survival (76 months, 95\% CI 39-101). In the

$\mathrm{ER}+\mathrm{Her} 2+$ group, one patient was still alive and shown as censored (+) at the end of the curve

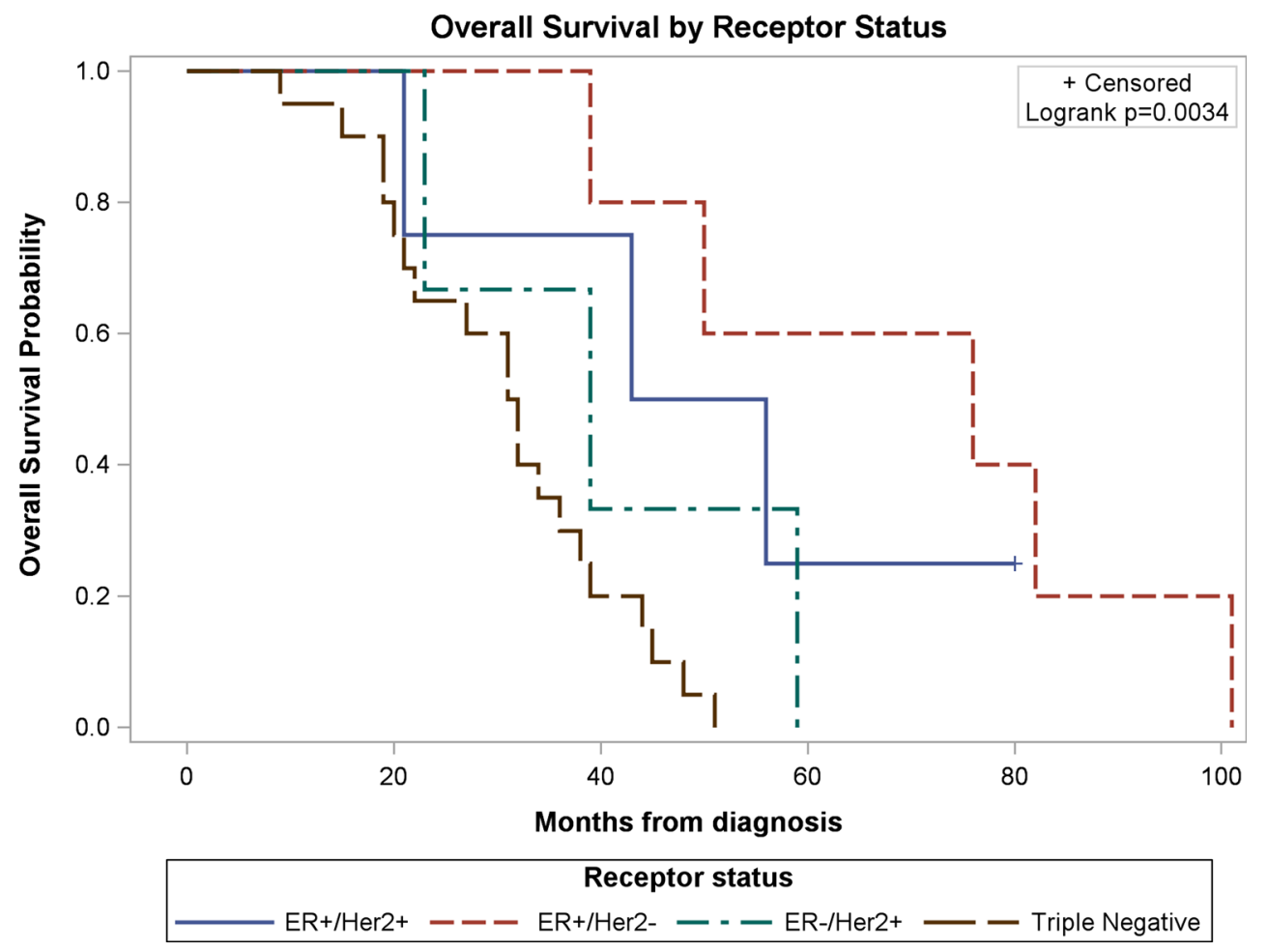


Table 3 Mutation analyses in single, pooled, and/or CTCs clusters

\begin{tabular}{|c|c|c|c|}
\hline $\begin{array}{l}\text { Patient } \\
\text { ID \# }\end{array}$ & $\begin{array}{l}\text { Mutations in tissue } \\
\text { samples }\end{array}$ & CTCs (single, pools or clusters) & WBC control \\
\hline B62630 & $\begin{array}{l}\text { TP53 S215G } \\
\text { (chest wall) }\end{array}$ & $\begin{array}{l}5 \text { single CTCs: } \\
\qquad 5 \text { CTCs: TP53 w. t. } \\
1 \text { cluster of CTCs: TP53 w. t. }\end{array}$ & $\begin{array}{l}5 \text { single WBCs: } \\
\qquad 5 \text { WBCs: TP53 w. t. }\end{array}$ \\
\hline$J 73299$ & $\begin{array}{l}\text { TP53 P190_H193>*E } \\
\text { (liver) }\end{array}$ & \begin{tabular}{|l|}
2 single CTCs: \\
$\bullet 2$ CTCs: TP53 P190_H193>*E
\end{tabular} & $\begin{array}{l}4 \text { single WBCs: } \\
\text { • } 4 \text { WBCs: TP53 w.t. }\end{array}$ \\
\hline R85453 & $\begin{array}{l}\text { TP53 R110 delG fs*13 } \\
\text { (breast biopsy) }\end{array}$ & $\begin{array}{l}6 \text { single CTCs: } \\
\text { - } 1 \text { CTCs: TP53 R110 delG fs*13 } \\
\text { - } 1 \text { CTC: TP53 R110 delC fs*13 } \\
\text { - } 4 \text { CTCs: TP53 w. t. } \\
1 \text { pool of } 14 \text { CTCs: TP53 R110 delC fs*13 }\end{array}$ & $\begin{array}{l}4 \text { single WBCs: } \\
\bullet 4 \text { WBCs: TP53 w. t. }\end{array}$ \\
\hline T77549 & $\begin{array}{l}\text { RB1 } 607+1 \mathrm{G}>\mathrm{C} \\
\text { (chest wall) }\end{array}$ & $\begin{array}{l}\text { single CTC: } \\
- \text { RB1 } 607+1 \mathrm{G}>\mathrm{C} \\
2 \text { pools of CTCs: } \\
\text {-1 pool of } 6 \text { CTCs: RB1 } 607+1 \mathrm{G}>\mathrm{C} \\
-1 \text { pool of } 4 \text { CTCs: RB1 w.t. } \\
\end{array}$ & $\begin{array}{l}1 \text { single WBC: } \\
\bullet \text { RB1 w. t. } \\
1 \text { pool of } 5 \text { WBCs: } \\
\bullet \text { RB1 w. t. }\end{array}$ \\
\hline L67504 & $\begin{array}{l}\text { TP53 R110 delC fs*13 } \\
\text { RB1 K720* } \\
\text { BRCA2 pA1326 fs*4 } \\
\text { (chest wall) }\end{array}$ & $\begin{array}{l}5 \text { single CTCs: } \\
\text { - } 2 \text { CTCs: TP53 R110 delC fs*13; RB1 K720* } \\
\text { - } 2 \text { CTCs: TP53 w. t.; RB1 w.t. } \\
\text { - } 1 \text { CTC: TP53 R110 delC fs*13; RB1 w.t. } \\
1 \text { cluster of } 3 \text { CTCs: } \\
\text { - TP53 R110 delC fs*13; RB1 K720* }\end{array}$ & $\begin{array}{l}3 \text { single WBCs: } \\
\bullet 2 \text { WBCs: TP53 w. t.; RB1 w.t.; } \\
\text { BRCA2 w.t. } \\
\text { - } 1 \text { WBC: TP53 w.t.; RB1 w.t.; } \\
\text { BRCA2 pA1326 fs*4 }\end{array}$ \\
\hline D84455 & $\begin{array}{l}\text { TP53 C229 fs*10 } \\
\text { ERBB2 S310F } \\
\text { ERBB2 V777L } \\
\text { PIK3CA K111E } \\
\quad \text { (chest wall) }\end{array}$ & $\begin{array}{l}5 \text { single CTCs: } \\
\text { - } 2 \text { CTCs: TP53 C229 fs*10; ERBB2 exon } 12 \text { S310F; ERBB2 exon } 24 \text { V777L; PIK3CA K111E } \\
\text { - } 1 \text { CTC: TP53 w.t.; ERBB2 S310F; ERBB2 V777L; PIK3CA w.t. } \\
\text { - } 1 \text { CTC: : TP53 C229 fs*10; ERBB2 exon } 12 \text { n.d.; ERBB2 exon } 24 \text { w.t.; PIK3CA n.d. } \\
\text { - } 1 \text { CTC: : TP53 n.d.; ERBB2 exon } 12 \text { S310F; ERBB2 exon } 24 \text { w.t.; PIK3CA n.d. } \\
1 \text { cluster of CTCs: TP53 C229 fs*10; ERBB2 S310F; ERBB2 V777L; PIK3CA K111E }\end{array}$ & $\begin{array}{l}4 \text { single WBC: } \\
\bullet 4 \text { WBCs: TP53 w.t.; ERBB2 w.t.; } \\
\text { PIK3CA w.t. }\end{array}$ \\
\hline
\end{tabular}

Single CTCs, pooled single CTCs, and/or CTCs clusters were recovered using DEPArray. Mutations in TP53, ErbB2, PIK3CA, and RB1 found in tumor tissue samples were detected in the CTCs

Intra-patient heterogeneous CTCs populations were found; w.t. wild type; n.d. non-done (because not enough amplified DNA)

from month 50). The TP53 S215G mutation is a missense mutation in exon 6 (Table 3). The other patients, J73299, R85453, L67504, and D84455, had TP53 mutations that produced a premature stop codon in the protein (Table 3). The liver biopsy of patient $\mathbf{J} 73299$ showed a mutation in TP53 exon 6, TP53 P190_H193 > *E; this mutation was also found in CTCs isolated from the patient's blood (Table 3). Two patients (R85453 and L67504) had a TP53 mutation in exon 4, TP53 R110 fs*13 (Table 3). In patient L67504, a C deletion (nucleotide 328, delC) was detected in the chest wall biopsy and the same mutation was found in the CTCs (Table 3). Patient R85453 showed a G deletion (nucleotide 329, delG) in p53 exon 4 in a breast biopsy sample (Table 1); while this mutation was also found in one CTC isolated from the patient, a second CTC revealed a $\mathrm{C}$ deletion (nucleotide 328 , delC) that was not previously detected in the tissue biopsy (Table 3). The chest wall biopsy of patient D84455 showed a TP53 C229 fs*10 mutation that was also found in three of five single CTCs analyzed and in one CTC cluster isolated from the patient's blood; one single CTC showed the TP53 wild-type allele and one CTC provided no data as we were unable to successfully amplify the region of interest (Table 3). In Table 4, the deleterious mutations in TP53 are shown.

The RB1 gene was mutated at high frequency in IBC patients; CTCs isolated from patients T77549 and L67504 were chosen to further study RB1 mutations in single CTCs (Table 3). RB1 splice mutation $607+1 \mathrm{G}>\mathrm{C}$ was detected in the chest wall biopsy from T77549 and this mutation was detected in one single CTC and in one pool of 6 CTCs isolated from the blood of that patient (Table 3). A second pooled cell sample containing 4 CTCs harbored $\mathrm{RB} 1$ wild type. The RB1 $607+1 \mathrm{G}>\mathrm{C}$ denotes the $\mathrm{G}$ to $\mathrm{C}$ substitution at nucleotide +1 of the intron (between exons 6 and 7) in the coding DNA positioned between nucleotide 607 and 608, resulting in low expression or partial inactivation of the RB1 protein. Patient L67504 showed a RB1 K720* mutation in her chest wall (Table 1); the RB1 K720* mutation was also found in two of five single CTCs and a cluster containing three CTCs that were isolated from the blood (Table 3). The RB1 K720* mutation is a nonsense variant, a substitution that produces an 


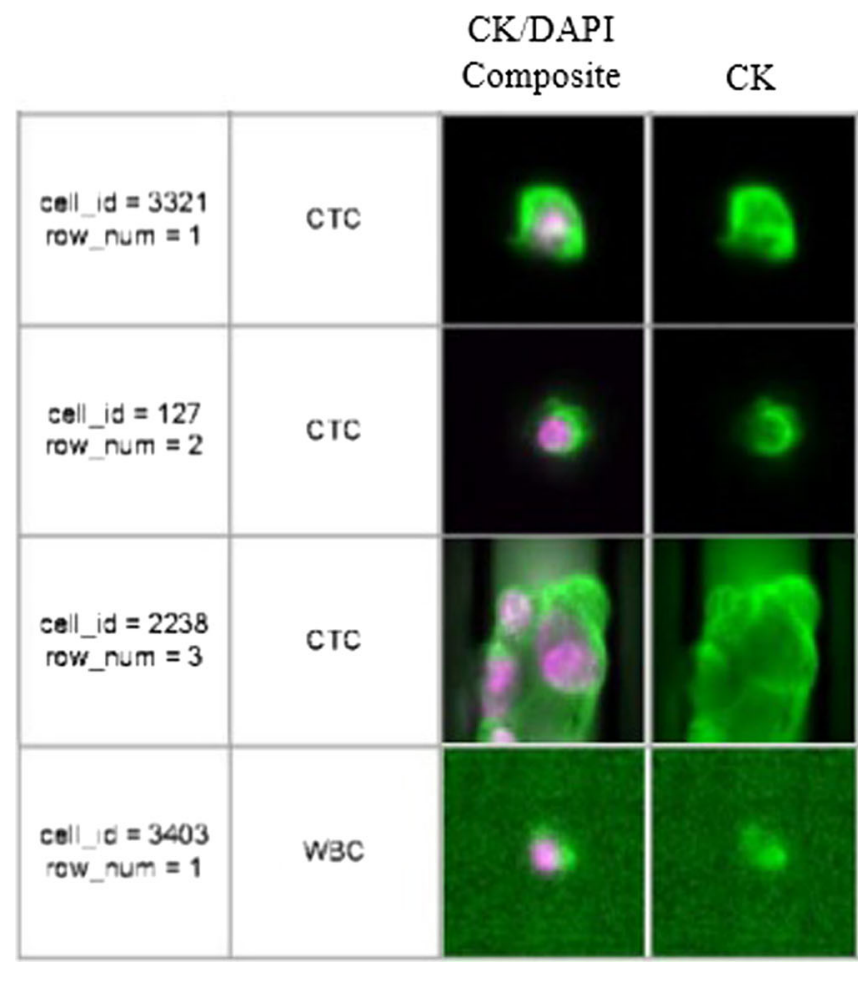

Fig. 2 Single and clusters of CTCs from a patient with triplenegative metastatic IBC visualized in the DEPArray ${ }^{\mathrm{TM}}$. Tumor cells were defined as presence of a clear DAPI-stained nucleus, CK-PEpositive cytoplasm, and CD-45-APC negativity. Separate images for PE (green), DAPI (magenta), APC (blue) fluorescence, bright field

immediate stop codon. This patient also showed a BRCA2 p.A1326 fs*4 mutation in her chest wall biopsy (Table 1); the BRCA2 p.A1326 fs*4 mutation was detected in one of three white blood cells (WBC) used as controls, suggesting that the BRCA2 mutation is a germline mutation. This mutation was not investigated in the isolated CTCs. In both patients that had RB1 mutations, some CTCs showed the RB1 mutations and others showed the wild-type RB1 allele (Table 3).

The chest wall biopsy from patient D84455 had two mutations in ErbB2: $\mathrm{S} 310 \mathrm{~F}$ in exon 12, and V777L in exon 24; this patient also had a mutation in PIK3CA K111E, in addition to the TP53 C229 fs*10 mutation previously described (Table 3 ). These mutations were studied in five single CTCs and one CTC cluster. Two single CTCs and the cluster showed all the mutations detected in the chest wall biopsy; another single CTC only showed the ErbB2 mutations (ErbB2 S310F and ErbB2 V777L) and wild-type alleles of TP53 and PIK3CA. Another single CTC showed the ErbB2 mutation on exon 12 (ErbB2 S310F), the wildtype allele on exon 24 , but the amplified DNA was not enough to study TP53 and PIK3CA in this cell (Table 3). The remaining single CTC showed the mutated TP53 (TP53 C229 fs*10) and ErbB2 exon 24 wild type. Results

\section{CD45/DAPI}

DAPI

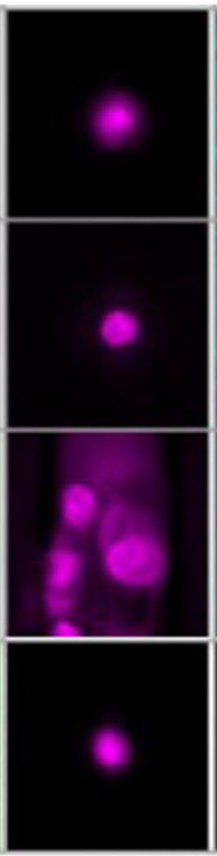

CD45

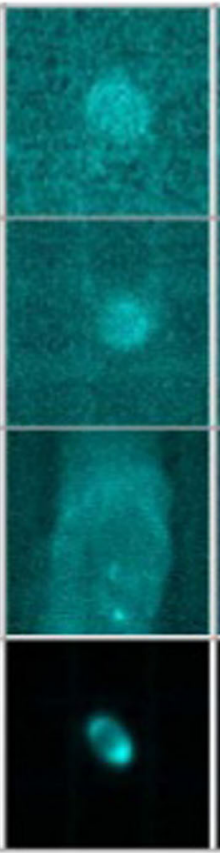

Composite

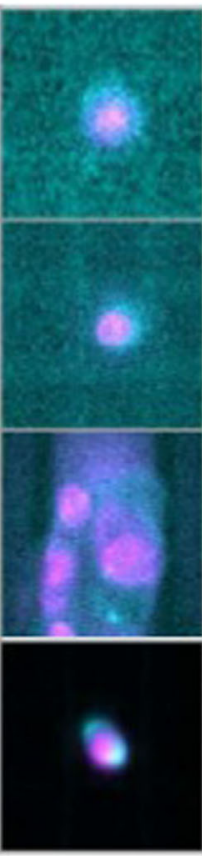

Brightfield

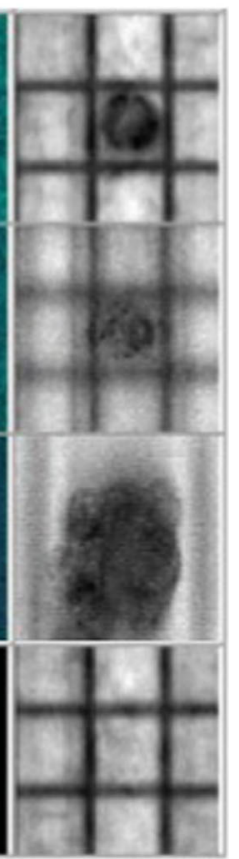

channels, and merged CK-PE/DAPI and CD45-APC/DAPI images are shown. Single CTCs and a cluster of CTCs from a metastatic triple-negative IBC patient (D84455) are shown; also, four white blood cells (WBC) collected to use as controls for the molecular studies are shown

indicated that patients D84455 and L67504, in which mutations in more than one gene were studied, had a heterogeneous population of CTCs (Table 3).

\section{Discussion}

Genomic alterations were studied in primary and/or metastatic tumor samples from 32 patients with IBC. Most of the patients had triple-negative IBC and had mutations in TP53, $\mathrm{RB} 1$, and/or PIK3CA. CTCs were detected in 28 of the 32 IBC patients included in this study. Single CTCs isolated from the blood of six of these patients showed the same mutations as primary or metastatic tumor samples indicating that CTCs can potentially be used to monitor disease progression. Our results show that mutations in driver genes found in the primary tumor and/or the metastasis in IBC patients could be identified in the CTCs. Furthermore, the mutational analysis of the TP53, RB1, PIK3CA, and ErbB2 genes revealed heterogeneity of CTCs.

Deleterious TP53 mutations found in tissue samples or pleural effusions of IBC patients were also present in CTCs isolated from their blood. In the majority of the IBC patients with TP53 mutations, these mutations resulted in a 
Table 4 TP53 deleterious mutations in IBC tumor and CTCs

\begin{tabular}{|c|c|c|c|c|}
\hline \multicolumn{5}{|c|}{ TP53 mutations found in CTCs } \\
\hline $\begin{array}{c}\text { Patient ID } \\
\#\end{array}$ & Exon & Mutation & Sequence & Effect \\
\hline$J 73299$ & 6 & P190_H193>*E & $\begin{array}{l}\text { aa: } 187 \\
\text { nt:566 GGT CTG GCC CCT CCT CAG CAT } \frac{\text { TAA GAG CTT ATC }}{\text { Stop codon }}\end{array}$ & $\begin{array}{l}\text { Premature } \\
\text { stop codon }\end{array}$ \\
\hline \multirow[t]{2}{*}{ R85453 } & \multirow[b]{2}{*}{4} & R110 delG fs*13 & $\begin{array}{l}\text { aa: } 109 \\
\text { Tt: } 325\end{array}$ & $\begin{array}{l}\text { Premature } \\
\text { stop codon }\end{array}$ \\
\hline & & R110 delC fs*13 & $\begin{array}{l}\text { aa: } 109 \\
\text { nt: } 325\end{array}$ & $\begin{array}{l}\text { Premature } \\
\text { stop codon }\end{array}$ \\
\hline L67504 & 4 & R110 delC fs*13 & $\begin{array}{l}\text { aa: } 109 \\
\text { nt: } 325\end{array}$ & $\begin{array}{l}\text { Premature } \\
\text { stop codon }\end{array}$ \\
\hline D84455 & 7 & $\mathrm{C} 229 \mathrm{fs} * 10$ & $\begin{array}{l}\text { aa: } 225 \\
\text { nt: } 674 \text { GTT GGC TCT GAC TGT AC CAC CAT CCA CTA CAA CTA CAT GTG } \frac{\text { TAA CAGT }}{\text { Stop codon }}\end{array}$ & $\begin{array}{l}\text { Premature } \\
\text { stop codon }\end{array}$ \\
\hline
\end{tabular}

The TP53 P190_H193>*E mutation is a 12 base pair (bp) deletion that causes the loss of amino acids at position 190 (P) to 193 (H), and the insertion of 6 nucleotides (TAA GAG) that produce a premature stop codon in the protein

TP53 R110 fs*13 is a frame shift deleterious mutation that causes a stop codon at position 122 (nucleotide 366 ) of TP53 with the loss of the protein

The TP53 C229 fs*10 is a mutation in exon 7 of TP53 consisting in a 2 bp. deletion

non-functional protein. A non-functional TP53 has been shown to offer survival advantages to the cancer cells by facilitating growth, anoikis resistance, and the emergence of a potentially more aggressive malignancy [19]. TP53 mutations are exceptionally frequent in cancer and are among the key driving factors in triple-negative breast cancer (TNBC) [20]. Furthermore, TP53 mutations are more frequent in inflammatory breast cancer $(50 \%)$ than in non-inflammatory breast cancer (20-30\%) [21, 22]. TP53 mutations have been shown to predict a poor response to anthracycline-based neoadjuvant chemotherapy [23-25]; others suggested that TP53 mutations confer sensitivity to taxane $[26,27]$. A recent study suggested that patients with TP53 mutations are more likely to respond to anthracycline/cyclophosphamide-based neoadjuvant chemotherapy [28]. Several clinical trials are ongoing to study TP53mutated breast cancer sensitivity to different chemotherapeutic agents. Other clinical trials are targeted towards either expression of the wild-type TP53, suppressing expression of mutated TP53, or strategies that involve targeting of the cell cycle regulator Wee-1 tyrosine kinase inhibitors (clinicaltrials.gov).

RB1 mutations were found in only the triple-negative IBC patients from this study, and all of these mutations render a premature stop codon and a non-functional RB1 protein. RB1 mutations were also detected in the CTCs. RB1 mediates cell cycle control and is frequently inactivated in human TNBC [29-31]. There are targeted inhibitors that are currently in advanced clinical testing for tumors harboring RB1 and PIK3CA mutations [32, 33].

One triple-negative IBC patient (D84455) with a deleterious TP53 mutation also showed two ErbB2 mutations (V777L and S310F). Both mutations activate ErbB2 by either affecting its auto-phosphorylation or phosphorylation of downstream substrates in breast cancer cells [34-36]. Initially, this patient had ER+ Her2+ invasive ductal carcinoma (IDC) in the left breast that was treated with standard local therapies over 2 years and this patient subsequently developed triple-negative IBC in the same breast [16] (Supplementary Information). This suggests that the ErbB2 pathway could be the driver of this patient's disease even in the absence of ErbB2 amplification. Furthermore, this patient had a PIK3CA K111E mutation which is also an activating mutation [37, 38]. All the mutations detected in the chest wall biopsy of patient D84455 were detected in the CTCs isolated from their blood. A heterogeneous population of CTCs were found in this patient with some CTCs showing the mutated genes 
and others showing different combinations of the mutated and wild-type genes.

It has been successfully demonstrated by single-cell sequencing that many breast cancers are composed of multiple distinct subclones [39]. Intra-patient cellular heterogeneity is widely reported in epithelial malignancies and it is expected that CTCs will also be heterogeneous [40-42]. Our results are consistent with previous findings which showed a heterogeneous pattern of genomic mutations on single CTCs obtained from breast, esophageal, and colorectal cancer patients [42-44].

Our results demonstrate that we were able to select uncontaminated CTCs by combining the CellSearch and DEPArray $^{\mathrm{TM}}$ systems. However, one disadvantage of the DEPArray $^{\mathrm{TM}}$ is that there is approximately $40 \%$ cell-loss, although the DEPArray cartridge is manually loaded with $14 \mu \mathrm{L}$ of sample, only $9.26 \mu \mathrm{L}$ of sample is injected into the micro-chamber of the cartridge. We found that in order to successfully isolate single CTC, samples with 20 CTCs or more should be used to load in the DEPArray cassette. In order to perform molecular analysis of CTCs in samples with less than 20 CTCs per $7.5 \mathrm{~mL}$ blood, multiple samples from the same patient could potentially be combined after the CellSearch and loaded in the DEPArray cassette.

However, despite the promise of CTCs as multifunctional biomarkers, there are still numerous challenges that hinder their incorporation into standard clinical practice. Some patients showed little to no CTCs even though their disease was progressing. This is the case for most of the patients with Her2-positive IBC, with the exception of patients K76386 and B62630 who developed a Her2-negative component during their disease progression; both had high number of CTCs. Patients with Her2-positive IBC were treated with Herceptin for a long period of time, so this could explain why CTCs were not present in their blood due to the high specificity of these antibodies. In addition, the CellSearch ${ }^{\mathrm{TM}}$, relies on the detection of the surface epithelial cell adhesion molecule EpCAM, and the existence of an EpCAM-negative subpopulation of CTCs had been described in patients with Her2-positive metastatic breast cancer [45]; therefore, it will be interesting to combine different pre-enrichment strategies with the DEPArray in order to study these cells, especially in Her2-positive IBC.

It has been shown that elevated CTC at baseline or at any time through the course of metastatic breast cancer is associated with worse prognosis; patients with $\geq 5$ CTCs/ $7.5 \mathrm{~mL}$ blood had a shorter overall survival compared with the patients with $<5 \mathrm{CTCs} / 7.5 \mathrm{~mL}$ blood, and elevated CTCs while on treatment ultimately are predictive of an ineffective therapy [13, 46]. Our data showed that the distribution of CTCs in the patients with serial blood draws during the treatments varied; many patients were initially CTCs negative but converted to positive and vice versa.
Based on our results, single time-point measurements of CTCs seem to be inadequate, and could result in incorrect microscopic disease staging. Collecting sequential blood samples for real-time monitoring of the efficacy of systemic therapies would offer new possibilities in evaluating targeted therapies based on genomic profiling of CTCs and improving the clinical management of patients with IBC. In order to implement these studies in future clinical practice, we are developing protocols in order to study mutations in single, pools, and clusters of CTCs using NGS and a panel of 15 genes frequently mutated in IBC.

This work demonstrates that the isolation and pooling of CTCs from IBC patients can be used for genomic analysis, both to initially identify targetable mutations where solid tumor samples are unavailable and to be used as a biomarker to reveal which cell populations are affected by the current or previous therapy. Our results suggest that CTCs represent the entire spectrum of the primary tumor and distal metastases for patients with IBC. Furthermore, our studies showed the presence of different CTCs subclones in the peripheral blood of IBC patients.

Acknowledgements We thank Andreas Papoutsis and Erich Klem from Cynvenio Biosystems for the RB1 K720* mutation analysis by NGS, and Francesca Fontana from Menarini Silicon Biosystems for her help with DEPArray protocols. We thank Dr. Jennifer Winn for the revision of patient clinical histories in Supplementary Information. We thank the Fox Chase Cancer Center Sequencing Facility.

Funding This work was performed under the grant NIH RO1 CA 138239-02 (PI: Cristofanilli).

\section{Compliance with ethical standards}

Conflict of interest Paul W. Dempsey is an employee of Cynvenio Biosystems. All remaining authors have declared no competing interests.

Research involving human participants Patients signed an informed consent and HIPAA certification from the Human Subject Protection Committee prior to sample collection. This study was approved by both the research review committee (RRC) and institutional research board (IRB) at Fox Chase Cancer Center.

Open Access This article is distributed under the terms of the Creative Commons Attribution 4.0 International License (http://crea tivecommons.org/licenses/by/4.0/), which permits unrestricted use, distribution, and reproduction in any medium, provided you give appropriate credit to the original author(s) and the source, provide a link to the Creative Commons license, and indicate if changes were made.

\section{References}

1. Cristofanilli M, Valero V, Buzdar AU, Kau SW, Broglio KR, Gonzalez-Angulo AM, Sneige N, Islam R, Ueno NT, Buchholz TA, Singletary SE, Hortobagyi GN (2007) Inflammatory breast 
cancer (IBC) and patterns of recurrence: understanding the biology of a unique disease. Cancer 110(7):1436-1444

2. Alpaugh ML, Tomlinson JS, Kasraeian S, Barsky SH (2002) Cooperative role of E-cadherin and sialyl-Lewis X/A-deficient MUC1 in the passive dissemination of tumor emboli in inflammatory breast carcinoma. Oncogene 21(22):3631-3643

3. Molckovsky A, Fitzgerald B, Freedman O, Heisey R, Clemons M (2009) Approach to inflammatory breast cancer. Can Fam Physician 55(1):25-31

4. Cristofanilli M, Buzdar AU, Hortobagyi GN (2003) Update on the management of inflammatory breast cancer. Oncologist 8(2):141-148

5. Dawood S, Cristofanilli M (2011) Inflammatory breast cancer: what progress have we made? Oncology (Williston Park) 25(3):264-273

6. Robertson FM, Bondy M, Yang W, Yamauchi H, Wiggins S, Kamrudin S, Krishnamurthy S, Le-Petross H, Bidaut L, Player AN, Barsky SH, Woodward WA, Buchholz T, Lucci A, Ueno NT, Cristofanilli M (2010) Inflammatory breast cancer: the disease, the biology, the treatment. CA Cancer J Clin 60(6):351-375

7. Hance KW, Anderson WF, Devesa SS, Young HA, Levine PH (2005) Trends in inflammatory breast carcinoma incidence and survival: the surveillance, epidemiology, and end results program at the National Cancer Institute. J Natl Cancer Inst 97(13): 966-975

8. Anderson WF, Schairer C, Chen BE, Hance KW, Levine PH (2005) Epidemiology of inflammatory breast cancer (IBC). Breast Dis 22:9-23

9. Levine PH, Veneroso C (2008) The epidemiology of inflammatory breast cancer. Semin Oncol 35(1):11-16

10. Alunni-Fabbroni M, Sandri MT (2010) Circulating tumour cells in clinical practice: methods of detection and possible characterization. Methods 50(4):289-297

11. Danila DC, Heller G, Gignac GA, Gonzalez-Espinoza R, Anand A, Tanaka E, Lilja H, Schwartz L, Larson S, Fleisher M, Scher HI (2007) Circulating tumor cell number and prognosis in progressive castration-resistant prostate cancer. Clin Cancer Res 13(23):7053-7058

12. Cohen SJ, Alpaugh RK, Gross S, O'Hara SM, Smirnov DA, Terstappen LW, Allard WJ, Bilbee M, Cheng JD, Hoffman JP, Lewis NL, Pellegrino A, Rogatko A, Sigurdson E, Wang H, Watson JC, Weiner LM, Meropol NJ (2006) Isolation and characterization of circulating tumor cells in patients with metastatic colorectal cancer. Clin Colorectal Cancer 6(2):125-132

13. Cristofanilli M, Budd GT, Ellis MJ, Stopeck A, Matera J, Miller MC, Reuben JM, Doyle GV, Allard WJ, Terstappen LW, Hayes DF (2004) Circulating tumor cells, disease progression, and survival in metastatic breast cancer. N Engl J Med 351(8): 781-791

14. Yu M, Ting DT, Stott SL, Wittner BS, Ozsolak F, Paul S, Ciciliano JC, Smas ME, Winokur D, Gilman AJ, Ulman MJ, Xega K, Contino G, Alagesan B, Brannigan BW, Milos PM, Ryan DP, Sequist LV, Bardeesy N, Ramaswamy S, Toner M, Maheswaran S, Haber DA (2012) RNA sequencing of pancreatic circulating tumour cells implicates WNT signalling in metastasis. Nature 487(7408):510-513

15. Lee JS, Magbanua MJ, Park JW (2016) Circulating tumor cells in breast cancer: applications in personalized medicine. Breast Cancer Res Treat 160(3):411-424

16. Ali SM, Alpaugh RK, Downing SR, Stephens PJ, Yu JQ, Wu H, Buell JK, Miller VA, Lipson D, Palmer GA, Ross JS, Cristofanilli M (2014) Response of an ERBB2-mutated inflammatory breast carcinoma to human epidermal growth factor receptor 2-targeted therapy. J Clin Oncol 32(25): e88-91

17. Ali SM, Alpaugh RK, Buell JK, Stephens PJ, Yu JQ, Wu H, Hiemstra CN, Miller VA, Lipson D, Palmer GA, Ross JS,
Cristofanilli M (2014) Antitumor response of an ERBB2 amplified inflammatory breast carcinoma with EGFR mutation to the EGFR-TKI erlotinib. Clin Breast Cancer 14(1):e14-16

18. Fernandez SV, Bingham C, Fittipaldi P, Austin L, Palazzo J, Palmer G, Alpaugh K, Cristofanilli M (2014) TP53 mutations detected in circulating tumor cells present in the blood of metastatic triple negative breast cancer patients. Breast Cancer Res 16(5):445

19. Zhang Y, Lu H, Dazin P, Kapila Y (2004) Squamous cell carcinoma cell aggregates escape suspension-induced, p53-mediated anoikis: fibronectin and integrin alphav mediate survival signals through focal adhesion kinase. J Biol Chem 279(46): 48342-48349

20. Walerych D, Napoli M, Collavin L, Del Sal G (2012) The rebel angel: mutant p53 as the driving oncogene in breast cancer. Carcinogenesis 33(11):2007-2017

21. Sawaki M, Ito Y, Akiyama F, Tokudome N, Horii R, Mizunuma $\mathrm{N}$, Takahashi S, Horikoshi N, Imai T, Nakao A, Kasumi F, Sakamoto G, Hatake K (2006) High prevalence of HER-2/neu and p53 overexpression in inflammatory breast cancer. Breast Cancer 13(2): 172-178

22. Turpin E, Bieche I, Bertheau P, Plassa LF, Lerebours F, de Roquancourt A, Olivi M, Espie M, Marty M, Lidereau R, Vidaud $M$, de The H (2002) Increased incidence of ERBB2 overexpression and TP53 mutation in inflammatory breast cancer. Oncogene 21(49):7593-7597

23. Aas T, Borresen AL, Geisler S, Smith-Sorensen B, Johnsen H, Varhaug JE, Akslen LA, Lonning PE (1996) Specific P53 mutations are associated with de novo resistance to doxorubicin in breast cancer patients. Nat Med 2(7):811-814

24. Berns EM, Foekens JA, Vossen R, Look MP, Devilee P, HenzenLogmans SC, van Staveren IL, van Putten WL, Inganas $M$, Meijer-van Gelder ME, Cornelisse C, Claassen CJ, Portengen H, Bakker B, Klijn JG (2000) Complete sequencing of TP53 predicts poor response to systemic therapy of advanced breast cancer. Cancer Res 60(8):2155-2162

25. Kandioler-Eckersberger D, Ludwig C, Rudas M, Kappel S, Janschek E, Wenzel C, Schlagbauer-Wadl H, Mittlbock M, Gnant M, Steger G, Jakesz R (2000) TP53 mutation and p53 overexpression for prediction of response to neoadjuvant treatment in breast cancer patients. Clin Cancer Res 6(1):50-56

26. Gluck S, Ross JS, Royce M, McKenna EF Jr, Perou CM, Avisar $\mathrm{E}, \mathrm{Wu} \mathrm{L}$ (2012) TP53 genomics predict higher clinical and pathologic tumor response in operable early-stage breast cancer treated with docetaxel-capecitabine \pm trastuzumab. Breast Cancer Res Treat 132(3):781-791

27. Wahl AF, Donaldson KL, Fairchild C, Lee FY, Foster SA, Demers GW, Galloway DA (1996) Loss of normal p53 function confers sensitization to Taxol by increasing G2/M arrest and apoptosis. Nat Med 2(1):72-79

28. Wang Y, Xu Y, Chen J, Ouyang T, Li J, Wang T, Fan Z, Fan T, Lin B, Xie Y (2016) TP53 mutations are associated with higher rates of pathologic complete response to anthracycline/cyclophosphamide-based neoadjuvant chemotherapy in operable primary breast cancer. Int J Cancer 138(2):489-496

29. Sellers WR, Novitch BG, Miyake S, Heith A, Otterson GA, Kaye FJ, Lassar AB, Kaelin WG Jr (1998) Stable binding to E2F is not required for the retinoblastoma protein to activate transcription, promote differentiation, and suppress tumor cell growth. Genes Dev 12(1):95-106

30. Whitaker LL, Su H, Baskaran R, Knudsen ES, Wang JY (1998) Growth suppression by an E2F-binding-defective retinoblastoma protein (RB): contribution from the RB C pocket. Mol Cell Biol 18(7):4032-4042

31. Jiang Z, Jones R, Liu JC, Deng T, Robinson T, Chung PE, Wang S, Herschkowitz JI, Egan SE, Perou CM, Zacksenhaus E (2011) 
RB1 and p53 at the crossroad of EMT and triple-negative breast cancer. Cell Cycle 10(10):1563-1570

32. Cancer Genome Atlas N (2012) Comprehensive molecular portraits of human breast tumours. Nature 490(7418):61-70

33. Carey L, Winer E, Viale G, Cameron D, Gianni L (2010) Triplenegative breast cancer: disease entity or title of convenience? Nat Rev Clin Oncol 7(12):683-692

34. Bose R, Kavuri SM, Searleman AC, Shen W, Shen D, Koboldt DC, Monsey J, Goel N, Aronson AB, Li S, Ma CX, Ding L, Mardis ER, Ellis MJ (2013) Activating HER2 mutations in HER2 gene amplification negative breast cancer. Cancer Discov 3(2):224-237

35. Greulich H, Kaplan B, Mertins P, Chen TH, Tanaka KE, Yun CH, Zhang X, Lee SH, Cho J, Ambrogio L, Liao R, Imielinski M, Banerji S, Berger AH, Lawrence MS, Zhang J, Pho NH, Walker SR, Winckler W, Getz G, Frank D, Hahn WC, Eck MJ, Mani DR, Jaffe JD, Carr SA, Wong KK, Meyerson M (2012) Functional analysis of receptor tyrosine kinase mutations in lung cancer identifies oncogenic extracellular domain mutations of ERBB2. Proc Natl Acad Sci U S A 109(36):14476-14481

36. Herter-Sprie GS, Greulich H, Wong KK (2013) Activating mutations in ERBB2 and their impact on diagnostics and treatment. Front Oncol 3:86

37. Rudd ML, Price JC, Fogoros S, Godwin AK, Sgroi DC, Merino MJ, Bell DW (2011) A unique spectrum of somatic PIK3CA (p110alpha) mutations within primary endometrial carcinomas. Clin Cancer Res 17(6):1331-1340

38. Zheng G, Tseng LH, Chen G, Haley L, Illei P, Gocke CD, Eshleman JR, Lin MT (2015) Clinical detection and categorization of uncommon and concomitant mutations involving BRAF. BMC Cancer 15:779

39. Robinson DR, Wu YM, Vats P, Su F, Lonigro RJ, Cao X, Kalyana-Sundaram S, Wang R, Ning Y, Hodges L, Gursky A,
Siddiqui J, Tomlins SA, Roychowdhury S, Pienta KJ, Kim SY, Roberts JS, Rae JM, Van Poznak CH, Hayes DF, Chugh R, Kunju LP, Talpaz M, Schott AF, Chinnaiyan AM (2013) Activating ESR1 mutations in hormone-resistant metastatic breast cancer. Nat Genet 45(12):1446-1451

40. Klein CA (2009) Parallel progression of primary tumours and metastases. Nat Rev Cancer 9(4):302-312

41. Marusyk A, Almendro V, Polyak K (2012) Intra-tumour heterogeneity: a looking glass for cancer? Nat Rev Cancer 12(5):323-334

42. Stoecklein NH, Klein CA (2010) Genetic disparity between primary tumours, disseminated tumour cells, and manifest metastasis. Int J Cancer 126(3):589-598

43. Ignatiadis M, Rothe F, Chaboteaux C, Durbecq V, Rouas G, Criscitiello C, Metallo J, Kheddoumi N, Singhal SK, Michiels S, Veys I, Rossari J, Larsimont D, Carly B, Pestrin M, Bessi S, Buxant F, Liebens F, Piccart M, Sotiriou C (2011) HER2-positive circulating tumor cells in breast cancer. PLoS ONE 6(1):e15624

44. Riethdorf S, Muller V, Zhang L, Rau T, Loibl S, Komor M, Roller M, Huober J, Fehm T, Schrader I, Hilfrich J, Holms F, Tesch H, Eidtmann H, Untch M, von Minckwitz G, Pantel K (2010) Detection and HER2 expression of circulating tumor cells: prospective monitoring in breast cancer patients treated in the neoadjuvant GeparQuattro trial. Clin Cancer Res 16(9): 2634-2645

45. Giordano A, Gao H, Anfossi S, Cohen E, Mego M, Lee BN, Tin S, De Laurentiis M, Parker CA, Alvarez RH, Valero V, Ueno NT, De Placido S, Mani SA, Esteva FJ, Cristofanilli M, Reuben JM (2012) Epithelial-mesenchymal transition and stem cell markers in patients with HER2-positive metastatic breast cancer. Mol Cancer Ther 11(11):2526-2534

46. Swaby RF, Cristofanilli M (2011) Circulating tumor cells in breast cancer: a tool whose time has come of age. BMC Med 9:43 